\title{
Supporting and Non-supporting Entities of the Mayor in Polish Municipalities with Cohabitation
}

\author{
MONIKA SIDOR, KATARZYNA KUĆ-CZAJKOWSKA, JUSTYNA WASIL
}

\begin{abstract}
In the present legal state, the mayor is an important political leader in Polish municipalities. On account of being elected in direct elections and enjoying a broad range of powers, he/she is a natural local leader. Another municipal authority is the council, which fulfills decision-making and supervisory functions. Whether the mayor can effectively act depends on the outcome of elections and, in consequence, the council's composition. Elections may lead to the phenomenon of cohabitation. This occurs when the mayor does not have the support of an absolute majority in the council or represents the opposite political camp to the members of the municipal council. Taking into account 1,737 questionnaires and 74 interviews, it turns out that mayors do not operate in a political and administrative vacuum. Even if they make decisions on their own, they need internal (councilors, local government employees) and external (entrepreneurs, representatives of NGOs, the Catholic Church, political parties) help.
\end{abstract}

Keywords: $\bullet$ cohabitation $\bullet$ mayor $\bullet$ council $\bullet$ municipality $\bullet$ Poland

CoRRESPONDENCE AdDREss: Monika Sidor, Ph.D., Assistant Professor, Maria CurieSkłodowska University in Lublin, Faculty of Political Science and Journalism, ul. Głęboka 45, 20-612 Lublin, Poland, email: monika.sidor@ poczta.umcs.lublin.pl. Katarzyna KućCzajkowska, Ph.D. Assistant Professor, Maria Curie-Skłodowska University in Lublin, Faculty of Political Science and Journalism, ul. Głęboka 45, 20-612 Lublin, Poland, email: katarzyna.kuc-czajkowska@ poczta.umcs.lublin.pl. Justyna Wasil, Ph.D., Assistant Professor, Maria Curie-Skłodowska University in Lublin, Faculty of Political Science and Journalism, ul. Głęboka 45, 20-612 Lublin, Poland, email: justyna.wasil@poczta.umcs.lublin.pl.

https://doi.org/10.4335/18.3.625-645(2020)

ISSN 1581-5374 Print/1855-363X Online C) 2020 Lex localis

Available online at http://journal.lex-localis.press. 
The relationships between the authorities in Polish local government, and - in a broader context - in the local community, were formed by different experiences: from the natural formation of local government in the twenty-year interwar period to the replacement of self-governance with the hierarchical territorial administration in the Polish People's Republic to the restitution of the municipality after the 1989 political transformation. The reintroduction of local government in 1990 brought about a transition from centralisation of power, tasks and assets to their decentralisation ${ }^{1}$, additionally reinforced by the rule of subsidiarity. This meant changes in local leadership: from the appointed head of the municipality to the municipal board elected in indirect elections among councilors, and from appointed members of municipal national councils to councilors elected in direct elections by constituents. These transitions were accompanied by a shift in the perception of municipal authorities and local leaders. The mayor was expected to fulfill administrative functions, as well as playing the role of a political leader and, at the same time, that of a manager (Regulski 2005: 114, 115).

The core of local government values consists of three attributes: pluralism, participation, and responsiveness (meeting the needs of the local community) (Wolman, 1995: 139). In Poland, the model of local government based on the above principles was reinstated as a consequence of enacting The Local Government Act of 8 March 1990. Residents, through the bodies elected in direct elections and a local referendum, exercise power in the process of democratising local public life. The legislator provided for a dominant constitutional position of the municipal council (decision-making and supervisory body directly elected by constituents) in relation to a five-person board (an executive body elected in indirect elections by the council). This model functioned with some modifications for 12 years. Firstly, the legislator changed the number of councilors, which did not affect the relationships between the bodies. Secondly, recognising the need to strengthen the position of the executive body in relation to the decision-making and supervisory body in the municipality, the legislator gradually introduced a more complicated procedure for removing the mayor. In 2002, a direct mode of electing the executive in the municipality was adopted, along with the possibility of removing the mayor through a referendum (The Local Government Act of 8 March 1990 (Dz. U. [Journal of Laws] of 1990, no. 16, item 95, as amended)). In this way, the model of municipal self-government changed from parliamentary to presidential (Larsen, 2005: 200-203). It was part of a general trend in local governments in Central-European Europe. On account of the mode of election direct - and the broad range of his/her powers, the mayor became a natural local leader. 
Direct elections of the municipal authorities (the council and the mayor) make it possible for the phenomenon of cohabitation to occur in the municipality, i.e. cogovernance by the authorities, the executive body, and the decision-making and supervisory one, coming from different political and ideological camps, in the situation when the mayor, elected by constituents, does not enjoy the support of the absolute majority in the council or represents the opposite political camp to the council. For this reason, the mayor, commencing his/her term of office, cannot take councilors' support for his/her actions for granted. Cohabitation can take different forms: peaceful cohabitation (when two bodies cooperate with each other) or conflict cohabitation (when the majority in the council impedes the executive's actions in the local decision-making process). The phenomena described above only to a small extent, follow from the parties' differences. Partyrelated conflicts, above all, arise in cities. In rural municipalities, on the other hand, the reasons behind conflicts are different, often of a personal nature, e.g. the majority of councilors come from the election committee of the previous mayor (Sidor, Kuć-Czajkowska and Wasil, 2017: 18-48).

The aim of the present paper is to characterise entities, people, and groups supporting the mayor in the decision-making process and creating the local policy development. The research focused on municipalities with cohabitation in Poland. The following questions were posed in the paper: What people/entities/organisations support the mayor in the case of cohabitation in the municipality? Where does the mayor look for support, and on what groups, people, and entities can he/she count in the case of lack of agreement between the local authorities? Are there any differences in support groups, depending on the type of municipality, i.e. rural, urban or urban-rural?

Networks of relationships in local communities are subject of research carried out by, among others, J. Kurczewska (2008), M. S. Szczepański (2018), A.B. Tanguay and B.J. Kay (1991), as well as C.A. Cooper, A.J. Nownes and S. Roberts (2005). The political and administrative relations were explored by the American researcher J. Svara (1998).

The paper uses a descriptive method for characterising the local community structure, including groups that can support the mayor in his/her activity and fostering local development. In order to achieve the research objectives, the following methods were applied: qualitative (postal questionnaires), quantitative (extended interviews), and comparative in analysing the outcomes of empirical research.

The main part of the paper concentrates on the results of all-Poland research on cohabitation conducted among councilors and mayors in the 2014-2018 term of office. The research comprised three stages. The first one consisted in analysing the data from the National Electoral Commission (PKW). The outcomes of voting 
in the local government elections of 2010 and 2014 in all Polish municipalities were examined. The intention was to identify municipalities in which - according to the results of the elections - the mayor did not have the majority of councilors from his/her election committee in the municipal council. After the 2014 elections, cohabitation occurred in 49.5 percent of Poland's municipalities. In the second stage of research, the questionnaires were sent to councilors and mayors of seven provinces (out of 16) with the highest percentage of municipalities with cohabitation recurring in the elections in 2010 and 2014. In the end, 1,737 questionnaires were returned and examined ${ }^{2}$. In the third stage, altogether, 20 municipalities (urban, urban-rural and rural) were chosen on the basis of the answers from the questionnaires. In those municipalities, 74 extended interviews were conducted with representatives of different environments: local government authorities (councilors of the coalition, opposition, independent, mayors) and residents (NGO workers, journalists, village administrators) (Sidor, KućCzajkowska and Wasil, 2017: 18-48).

The paper consists of four sections. The first one concerns the issue of authorities, elites and management styles. After elections, mayors do not operate in a political and administrative vacuum. Even if they make decisions on their own, they need internal and external help. In the second, the third, and fourth part of the paper, groups/people are pointed out which/who influence the executive body in the municipality. Consequently, the following relationships were scrutinised: between the mayor and councilors, between the mayor and local government employees, and between the mayor and other support groups, such as entrepreneurs, or representatives of NGOs or the Catholic Church.

\section{Authorities, local elite and management styles}

Along with families, local communities provide a basis for social structures, and municipalities are their political and institutional expression (Tuziak, 2014: 139). Research on governing (political) elites were conducted by the Italians G. Mosca and V. Pareto (1935. After: Wiatr 2008: 19-21). The relationships between power and elites in the democratic system were described in the 1930s by H. Lasswell (After: Żyromski 1984: 270-272). Analysing the literature in English, two approaches can be observed. The first is connected with the theory of elites: political, economic and military elites govern local communities and an ordinary citizen cannot understand, influence or effectively defy them (F. Hunter 1953; C. W. Mills 1956). The second, pluralistic approach (precursors: R. Dahl 1961; P. Bachrach, M.S. Baratz 1962) questions the existence and influence of pervasive elites. The identification of key issues in taking decisions, determination of those involved in the decision-making process, their real behavior, and their role in political conflicts are considered pivotal (Drzonek 2013: 31-34). 
Intrinsic to the structure of communities and playing a vital role in their functioning are local authorities and elites. They create a local system of various connections. Local authorities and elites are influential in terms of opinions, evaluations and model behavior for local people. They also act as organizers, managers and supervisors, integrating and motivating the public. To explain the role and functions of local authorities and elites the following theories can be used: traditional political culture theory, the theory of local culture uniqueness and social capital theory.

In the first theory, the source of authority is seen in the character of a local community where the sense of community and hierarchy are of great importance. Authority in local communities guarantees stability and maintenance of their values (Tuziak, 2014: 163-164).

The second theory explaining the importance of authority points to the distinctiveness of the worlds built by local cultures, where the uniqueness of a given community, the degree of its inaccessibility and its autonomy are emphasized. Authority in such a community intermediates between the local society and the outside world, facilitating its accommodation to new requirements.

In the third theory, authority is perceived from the perspective of social capital. The importance of an authority displays itself in its integrative, communicative, and motivational functions. It is the strength of local communities to act together led by an authority. In this conception, authority stands for people or institutions that have given recognition and trust resulting from their moral values, knowledge, or professionalism. An authority creates communal initiatives, is open to cooperation and actions which it undertakes are favorable and supportive to community members (Tuziak, 2014: 165). It appears that in a municipality, which is a political and an administrative institution, such an authority should be possessed by local administrative bodies, namely the mayor and the municipality council. Electing such political elite should be based on the authority granted to them in a given local community. Lack of this component may be a sign of weakness of the community and low social capital.

Elites in local government include the most active actors, i.e. local government activists, heads of the most important local institutions, local entrepreneurs, and informal leaders, so inhabitants enjoying big authority. An elite should support a pro-growth direction of changes, and not stand for revindication or a quest for temporary benefits, be it collective or private (Stokłosińska 2015: 114). Similarly, Nocoń (2008: 13) lists, among elites at a municipal level in Poland, the following people: the mayor, his/her deputies, holders of high positions in the municipal council (the head and the deputy head of the council, the head of the commission), and influential councilors. 
As regards the context of power in the local community, the following elites can be distinguished:

- decision-making elites - people holding positions in the bodies of local government,

- elites of political influence, other interest groups,

- articulatory elites, i.e. constituents which act institutionally, although they are not a formalised group (Drzonek 2013: 87).

There are a few categories of authority in the structure of local communities, such as: the authority of power (e.g. mayor), clerical authority (institutional employees, e.g. municipal clerks), religious authority (e.g. local clergymen), the authority of skill and service (teachers, doctors) and authority of management and economy (entrepreneurs, CEOs) (Tuziak, 2014: 173).

Given the subject of the research, the first issue to concentrate on is the authority of power, which consists of two elements. One is non-personal power resulting from a range of tasks and positions (formal authority). The broader the range, the stronger the influence (Tuziak, 2014: 174). Immediate formal authority in a Polish municipal government is a result of the range of competence of the executive body and its position strengthened by direct elections. The other component of the power of authority is informal power based on executive aptitude, management skills, personality and personal values (Tuziak, 2014: 174).

In the context of municipal government, decision-making style is crucial. Considering the two dimensions: the mindset (logical and rational or creative and intuitive) and the so-called 'tolerance for ambiguity' (high or low level of uncertainty), there are four decision-making styles:

1) analytical - a combination of rational thinking with a high tolerance for ambiguity,

2) magisterial - rational thinking with a low tolerance for ambiguity,

3) conceptual - focusing on a long-term perspective with intuitive thinking and a high tolerance for ambiguity,

4) behavioral - intuitive thinking with a low tolerance for ambiguity as well as a simultaneous ability to cooperate and openness to suggestions (Robbins and DeCenzo, 2002: 192-193).

Magisterial and/or behavioral styles, which may be corresponding, appear to dominate in a municipal government. It results from the characteristics of administration in the local government, where decisions cannot be uncertain or risky as the government has public funds at their disposal.

From the perspective of political sciences, decision-making style is one of the indicators of the general leadership style. Not to analyse different leadership models in-depth, custom classification divides them into autocratic and 
democratic (Bodio and Załęski, 2007: 383). Considering the local level, in an autocratic leadership, the executive body defines goals and resources needed for their achievement, and decisions are made by one person. Autocrats also have significant control over their subordinates. In a democratic model, the local leader strives for an agreement between different groups, a compromise and a certain form of decisions (Bodio and Załęski, 2007: 383). Here, in local communities, there are various interest (pressure) groups. They are able to execute projects together and represent a common interest to public authorities (MilczarekAndrzejewska and Tłaczała, 2012: 196). They act independently from political parties and are not striving for power, but for a public decision which they can benefit from. The decision is an expression of their political, economic or cultural interest. Critics of such interest groups often blame them for destructive behaviour which boosts corruption or favouring one over another. Supporters of such groups emphasize their influence on decision processes by expressing the needs of local community and see them as a constructive element that creates public politics (Chmaj, Sokół and Żmigrodzki, 1997: 12-13).

Apart from interest groups, other authorities of power may have an impact on the decision-making process. Along with local governing bodies called administrators (mayor, municipal council), there is also the authority of a representative and authority of control and order. A representative can be a district councilor, regional councilor or an MP who is connected in a certain way to a local community. Whereas an authority of control and order is the chief of police, metropolitan police or a fire department (Tuziak, 2014: 174). Analysis of the material for research on cohabitation shows that volunteer fire departments play an important role in rural municipalities. It seems they should be qualified as interest groups as well, however not as an authority of control and order.

Moreover, in local communities, there are, as named by J. Szumski (2014: 81-83), opinion- and culture-forming groups. They act separately, however, some participants may be members of both at the same time. Members of an opinionforming group, for example, journalists, professionally formulate opinions on various subjects, including social and political issues. Culture-forming groups on the other hand, consist of culturally creative environments, such as writers, painters or actors. The latter, as results of cohabitation research show, has no impact on political and administrative relations in a municipality, with very few exceptions.

For the purposes of this paper, the term 'support groups' will be used to define groups which at times are classic interest groups and other times they support mayors as a result of professional relations. Local government employees are an interest group trying to maintain the status quo in a municipality because they are afraid of losing their job. 
Since 2002, political and administrative relationships have been influenced by such factors as, among others, the doubly strengthened role of the mayor. This is because, on the one hand, both the mayor and councilors are elected in democratic elections, forming a local political elite. On the other hand, local government administration in the municipality is supervised by the mayor, who is the superior of local government employees and head of the municipal office. The mayor manages the current affairs of the local community and represents it before third parties. He/she executes resolutions of the municipal council and tasks stipulated by the law. The municipal council (which has from 15 to 45 members, depending on the number of residents) passes resolutions, usually drafted by the mayor (the mayor, as the only body, is competent to draw up a draft budget) and executed by the mayor. It means that, in practice, councilors do not have many formal mechanisms for realising their own vision of the municipality's development. However, they can block the mayor's actions, e.g. by rejecting draft resolutions submitted by the mayor or avoiding sessions of the municipal council, which, in the absence of a quorum, renders sessions invalid. In the event of a conflict between the authorities, the municipal council can initiate dismissing the mayor by using the tool of a local referendum. Consequently, it is residents who eventually decide on dismissing the mayor ${ }^{3}$ (The Local Government Act of 8 March 1990 (Dz. U. [Journal of Laws] of 1990, no. 16, item 95, as amended)).

Relating the political system described above to the models and typologies universally applied in world research, it should be concluded that they are typical for the classic mayor-council and council-mayor division. The former relationship, mayor-council, is characteristic for authorities at a municipal level in Poland. This easy typology was further developed by American scholars, and e.g., P.E. Mouritzen and J. Svara (2002), who, taking various models of local government into account, proposed the following classification: strong-mayor form, committee-leader form, collective form and council-manager form (See: Sidor, Kuć-Czajkowska, Wasil 2017: 95-96). The political conditions allow Polish local government to be classified as a strong-mayor form. Subsequent research by Svara and Nelson $(2008,2010)$ led to singling out seven models of local government appropriate to American circumstances: council-manager, mayor-council-manager, empowered mayor-council-manager, mayor and council-administrator, mayor-council-administrator, mayor-administratorcouncil, mayor-council (Nelson and Nollenberger, 2011: 699). In Polish local government, for comparison, only one model is valid for all municipalities, i.e. mayor-council. The executive body (the mayor) accumulates a number of powers, which makes him/her a strong local leader. The mayor should be perceived as a good manager and a politician capable of building a coalition and resolving crises. However, as research proved, the mayor-council model of local government easily provokes conflicts (Nelson and Nollenberger 2011: 710, 712-713; Ihrke and 
Niederjohn 2005: 453-462). As a result, the executive body, especially in conflict situations, seeks different allies in order to carry out his/her plans and fulfil election promises.

In the inner structure municipal councils support mayors. Councils may, however, restrict their actions to formal issues resulting from the Local Government Act, such as granting the vote of approval to mayors, approving budgets, area development plans and other resolutions prepared by mayors (Local Government Act dated 8 March 1990 (consolidated text: Dz. U. [Journal of Laws] of 2017, items 1875, 2232)). Nevertheless, supporting mayors should be done in a broader sense and not be limited to formal issues. According to a mayor: Councilors should be a buffer dividing the mayor from residents. They should describe to the residents the financial situation, the budget, the plans, why this pavement is renovated and not the other etc. The reason may be that more people use this particular pavement, which seems to be a simple reason. Apart from that we have a group of rural leaders, who should cooperate with councilors and this big conglomerate should pass good news to the public, who is not always interested in what is happening in the municipality ( $\mathrm{E} 1 \mathrm{w})$. Therefore, a councilor as a representative of the local community should be in touch with residents, which is their responsibility anyway, and be a link between them and the executive body. Councilors have to communicate with the local community and integrate different areas by cooperating with the representatives of auxiliary units to the municipality (rural leaders, borough councilors).

In the questionnaire for the post survey (Table 1), councilors ( 850 out of 1737, i.e. 48.9 percent) were defined by the respondents (councilors, mayors) as a group supporting the executive body the most. Moreover, the respondents simultaneously pointed out councilors and the local community (7.6 percent), or councilors and entrepreneurs (2.3 percent), or councilors and NGO workers (3.8 percent). Both the councilors from the coalition party (54.5 percent) and the councilors from the opposition party (49.2 percent) agreed at this point. Almost a third of the mayors pointed at councilors to be the most support for them (See: Sidor, Kuć-Czajkowska and Wasil, 2017: 113, 243).

As Table 1 shows, the relations between municipal authorities influence how the respondents perceive councilors and that they are thought to be the most supportive to executive bodies. The majority of such opinions was submitted among the respondents who assessed the relations as very good (34.8 percent) or good (46.8 percent). The lowest percentage of answers pointing at councilors was submitted by the respondents who assessed the relations as bad (2.4 percent) or very bad ( 0.5 percent). Votes for other support groups were more scattered and it is difficult to determine such another prominent answer. Only 170 respondents chose a local community, which is 9.3 percent of all answers. As the abovementioned quotation states, a local community is hardly ever interested in 
the situation of the municipality. Assumingly, apart from elections, the majority of residents do not pay attention to the current administration of their municipality, except for issues which can affect their own affairs.

Some interesting answers were given in the category 'Other' and most importantly they were similar to the answers given by interviewees during extended interviews. The respondents named volunteer fire brigades, parish priests or mayor's "sycophants" (Sidor, Kuć-Czajkowska and Wasil, 2017: 114). As presented in Table I, the majority of the respondents from the category 'Other' describes relations between authorities as average ( 35 percent), bad ( 23.3 percent) or very bad (10 percent). Given the fact that Cramer's V equalled 0.2 , there is a connection between relations among authorities and choosing a support group for the mayor.

The survey shows that councilors are a dominant support group for the executive body, yet information gathered during extended interviews shows something different. In 20 municipalities, of which in 8 there was a conflict between authorities (conflict cohabitation), in 9 there was a peaceful cohabitation and in 3 initially conflict and then peaceful cohabitation (Sidor, Kuć-Czajkowska and Wasil, 2017: 42-43), the majority of interviewees have not chosen councilors as the most important support group for the mayor. There may be a few reasons for that.

First of all, in municipalities with conflict cohabitation this is caused by disagreements between the mayor and the opposition comprising most of the council, which is confirmed by one of the respondents: Previously councilors were joined by a mutual idea which they were trying to implement. Currently, this council is a bit strange, because there is a group of councilors who are always against everything (S3w).

Second of all, councilors are not prepared well enough for their post. This means that they have no or vague idea about laws of local self-government. According to a representative from a municipality with peaceful cohabitation: I sometimes doubt in the sense of having a council. (...) The act designates for district, regional and municipality governments district, regional and municipal councils respectively. I feel no support from the councilors because for me a councilor who comes to a meeting and does not look at the documents even once, in other words is unprepared, serves no citizen. What can he talk about with me? Municipal talk is simple. I have a comparison with district discussions, which were full of politics, questions, real discussions. Here everything is, not to sound disrespectful, rural. Silly questions are asked, which is an embarrassment in front of guests. Some questions are good. I would not want to criticize my council, but they have to be educated. I feel ill after our meetings. I do not like these meetings (U1w). 
Third of all, councilors are of no support to the mayor because he/she is supporting councilors as a more experienced member of the local government, which is proven by this quotation: We have to have constructive discussions (...). Currently the mayor is focused on presenting all issues to the councilors in a clear manner. They are in fact young and fresh as $80 \%$ of them have just been elected for the first time. The mayor tries to explain all issues to them very thoroughly. Of course, they all have their own opinions and look at things in a different way, however it is presented in a good way. We try to work on the issues together to work out a solution which would be a benefit to the municipality $(\mathrm{O} 1 \mathrm{u})$.

Fourth of all, councilors as representatives of a collegial, decision-making and supervising body do not support the mayor, because they take care of their own interests or force investments considering only their own constituency (they are a one-member pressure group): It is obvious that each councillor wants the best for their town. Perhaps it was difficult at the beginning because [the name of a town] is not prone to share. So are other towns and villages $(\mathrm{O} 2 \mathrm{o})$.

Fifth of all, there is a group other than councilors which is of great support to the mayor. As one of the respondents emphasized: I think that mayors do not need support because they have state clerks for that. Council is crucial for obtaining the vote of approval and approval of the budget, however the mayor needs no additional partners in management as they have many state clerks at their disposal and they are quite productive $(\mathrm{O} 2 \mathrm{u})$. Both groups: councilors and selfgovernment employees are obvious support groups for the executive body. Nonetheless, in conflict cohabitation their behaviour is different and state clerks can definitely support the mayor.

\section{Relations between the Mayor and Self-Government Employees}

In the survey only 3.2 percent of the respondents chose self-government employees as a support group for the executive body (Sidor, Kuć-Czajkowska and Wasil, 2017: 113). In spite of this, extended interviews clearly show that state clerks are a group which supports the executive body the most often. As a representative of a municipality observed: Having competent employees in each department is the main weapon for every self-government member because without them not much can be achieved (U3o).

The mayor is in fact a professional supervisor for the employees of the municipality office and organizational units. State clerks are a vocational group especially prone to employment changes when another person is elected for the mayor. A new leader often means a new management style in the municipality. To implement their ideas for leadership over a local community, the executive body can: hire a group of close associates (including a deputy and a secretary), fire head clerks who worked with the predecessor as a result of fear, disloyalty or 
wanting to maintain the status quo. In big cities there used to be mayor's offices consisting of closest advisors who came and went with the mayor (similarly to the offices in Polish ministries). No such institutions were found in the municipalities under research.

Anxiety over a new mayor, which may result in redundancies of self-government employees, is often an argument in the election campaign. One of the respondents stated: State clerks are a support for me. After the campaign (threats that the new mayor will be firing people), when I said I won't be firing, it means I won't be firing. I will be observing people. I came here not to fire skilful people, but to find a path we will all follow. If someone had not seen such an opportunity, they could have resigned. Some have, but some stayed, found their place, still work for me and are happy $(\mathrm{L} 4 \mathrm{w})$.

In case of conflict cohabitation, except for accusing the mayor of poor work, there is also criticizing his environment. In one of the researched municipalities a respondent observed that: There should be experts for special tasks. Here in this office however according to me, and not just me, there are no experts. There are people who are faithful to him and that meets his expectations in a way. They have to be loyal and subordinate and not some independent people who can be too much for him (W1u). What shows here is a strong leader with a weak and incompetent team. The leader makes decisions on their own and demands loyalty from their employees.

A different situation appeared in another municipality with conflict cohabitation where the mayor makes no decisions on his/her own. All decisions are made by the deputy and he/she shares no power with others $(\mathrm{U} 2 \mathrm{u})$. A weak leader with a strong deputy who supervises self-government employees. The actual leader in this local community is not the one elected by the community.

In yet another municipality with conflict cohabitation the position of state clerks is so strong that it weakens the authority of the mayor as a leader of the local community. According to a respondent: When it comes to clerks, he can rely on senior, but not so much on junior staff as they don't take their job seriously. They have noticed that the mayor doesn't punish them even if they don't work as they should, so they keep doing what they want (S3u). Another strong position belongs to a lawyer who is an employee of the municipality office or is hired by the office for a period of time (for example one day a week). When there is a conflict between municipal bodies, the lawyer becomes the "mayor's man". According to an interviewee: He/she [mayor] thinks and fabricates a story and then discusses it with the lawyer for it to be acceptable ( $\mathrm{S} 2 \mathrm{u}-2)$. This is how the disproportion between the executive body and the decision-making and controlling body in a municipality gets deepened, for example by obstructing access to legal advice. 
Moreover, using communal resources to strengthen their position is one of the accusations towards the mayor in municipalities with conflict cohabitation. According to an interviewee, the environment of the executive body are people who they hire, their families and groups which in a certain way use communal assets: It's mostly those people who in this situation have a job security and so have their families. They can benefit from municipal assets, for example by being able to buy something or take a lease or by other forms of acquiring a property. There are also those people who can use such assets but are not necessarily employees. It's like a gift-giving to different people or places, for example a playground, a road, a square, a dayroom etc. Those people create a kind of halo around the mayor and such an atmosphere among their relatives to support the mayor $(\mathrm{W} 1 \mathrm{u})$. Another representative of a local community adds that the mayor did not care about entrepreneurs: It is like a desert now. The municipality [the office] is the biggest employer here, considering the office, all organizational units, schools, library (...). It is like a mental shortcut that when you have a job it's thanks to the mayor because you owe him that and you should be thankful, loyal and supportive of him (W10).

There is this tendency that the more entrepreneurs there are, in a municipality, the weaker the position of the executive body is because the mayor stops being the main employer. The extended interviews also show that when an interviewee was not an employee of the municipality, organizational unit or communal company, their answers were fuller and objective. Whereas, when the respondent was a councillor and at the same time an employee, for example of an organizational unit in the municipality, they tried to put the mayor in a good light, not mentioning or hiding controversial facts. Therefore, independence from municipal administration can result in bigger social control over actions undertaken by the mayor.

\section{$5 \quad$ Relations Between the Mayor and Other Support Groups}

The private entrepreneurs mentioned above may be an external support for the executive body. A conclusion drawn from the survey is that 3.2 percent of the respondents pointed to 'local entrepreneurs' as the main support group (Sidor, Kuć-Czajkowska and Wasil, 2017: 113). Whereas, the extended interviews give an impression that in the majority of researched municipalities entrepreneurs limit their contacts with the office to the essential minimum, sometimes sponsoring municipal events. One of the respondents observed: I think in no municipality entrepreneurs willingly and selflessly help authorities. They rather demand something (U1o). What is more, in the researched municipalities, especially rural, entrepreneurs are scarce and sometimes they are sole proprietorships who have too much to do to be supporting the mayor $(\mathrm{S} 3 \mathrm{w})$. 
It seems entrepreneurs are a better-organized interest group (less support) when they are real representatives and see only measurable benefits. It happens more in urban-rural or urban municipalities rather than in rural municipalities. It expresses itself in participating in a local action group when in a rural municipality or creating an economic council which is an advisory body to the mayor (they shape investment directions).

A company making its products within a municipality may cause conflicts in a local community. That is the case when accusations of polluting the environment are made, which suggests health risk to residents. The mayor often defends the interest of the company more important than the local community as companies pay local taxes and hire employees from the municipality. The interest group which is thus created with an authority of skill and service, such as a doctor, can effectively articulate their disappointment becoming an opposition to the actions of the executive body. According to a representative of a municipality where such a conflict exists: Society is currently divided between the supporters of the mayor and their opponents. The supporters have their advisors and fans who give them ideas and possible solutions which may be criticised by the other group (W2u-2). In this case representatives of the disappointed residents became the municipal council majority which is in opposition to the mayor. They became "counterelite" (See: Bodio and Załęski, 2007: 395), which substitutes "the old" political elite in the council which the long-term mayor was used to.

The entities which not necessarily strive for changing current authorities, but are classic pressure groups, are non-government organizations (NGOs). As research on the third sector in Poland shows, it mostly cooperates with municipal selfgovernments ${ }^{4}$. This cooperation is however far from ideal and can cause frustration resulting from not being able to influence investments undertaken in the municipality. One of the researched municipalities is an example of this. On the one hand, the executive body admitted that advisory bodies, such as economic council, senior council or NGOs, are helpful with his/her work. On the other hand, they said: It happens often that when people who work actively for NGOs disagree with something, they want their word to be treated as final. And it is not so, because I cannot only consider one opinion even if it is clear and reasonable. I have to take into account other aspects, other voices, other people who are experts in a field or a project and then draw conclusions which will benefit all and not just one side, one group or one society. You always have to assess the situation first and make a choice which will be the least conflict-raising and beneficial to the whole town at the same time (W3w).

The superficiality of such actions is validated by one of the interviewees: According to us and the residents, these consultations are rather fake (...). It is because some actions for investments are undertaken long before that. What is currently executed is an aftermath because the first steps were made four or five 
years back and it was the president who assessed that this project is worth implementing as we could easily get subventions (W3o-1).

Public participation is in this case only partaking and not really having an impact on the decisions made in a municipality. Lack of partnership with NGOs may lead to divisions in a local community. From an interviewee's point of view: A mayor has a certain social support, support from different associations and local business. They also lack support from certain associations, local business or social organizations. In my opinion our mayor is supported by certain social organizations, however these are not associations which have been here for a long time (U2o). According to the respondent, new associations often count for the support of the executive body. Here the lack of support, especially financial, for NGOs in the local community resulted in a referendum on dismissing both municipal bodies which were in a conflict cohabitation ${ }^{5}$.

A private entity which is not an NGO but can support the mayor, not necessarily in his work but can diversify their position and contribute to their authority, is the Catholic Church (in the survey under 'Other'). According to an interviewee: They are strongly supported by the Church, Catholic associations and similar organizations. The mayor has met the bishop and this environment and has consulted many decisions with them (S1u-2). In another municipality with conflict cohabitation there are two parishes. One of the parish priests strongly supports the mayor ( $\mathrm{S} 3 \mathrm{u})$. Such a situation may cause the local church to be divided and a local religious authority to be used in political fights.

Analysing the research material from the extended interviews, some support groups are present depending on a municipality kind. In rural or urban-rural municipalities they are representatives of auxiliary units, namely rural leaders who distinctively mark their spot on the self-government map of Poland. Their post is deeply rooted in the mentality of residents from rural areas because of centuriesold tradition and internal recruitment. Rural leaders are always elected among local residents as opposed to the mayor who represents the whole municipality and is elected from a group outside of farmers (Matysiak, 2014: 57-68). They are an important support group for the executive body: Cooperation with rural leaders is something we did not have before. It is a mayor's idea. Rural leaders were invited to the meetings of the previous council. Now they have a separate meeting with the mayor once a month (Ł1u-3). A similar situation was described in a different municipality with conflict cohabitation where an interviewee appreciated the mayor's availability and possibility to discuss important matters for each rural area (S3o). As a result there can be a situation in a local community that the majority of councilors are in opposition to the mayor, but the majority of representatives from auxiliary units support the mayor. Also, in rural areas farmer's wives' associations and volunteer fire brigades are major support groups. Such a support may be misleading: The volunteer fire brigade is probably in good 
relations with the mayor. I am not sure how it functions, but I think he used to be a fire-fighter. When the brigade finds something odd, they just stop cooperating (S2o).

In urban municipalities it is political parties that elect the mayor: They are very loyal to the mayor or even devoted, I would say ( $€ 2 \mathrm{u})$. It can also be quasi-political parties: It's not really a political party as it's a local committee. However, it functions like a political party because it has its long history and its supporters. Clerks, entrepreneurs, residents (EU subventions) (S1o-1).

The last research group is authorities of power - representatives. In one of the municipalities with conflict cohabitation there was a district councillor with a vast knowledge about relations in the municipality, who supported the mayor and advised them to find solutions to different problems. In another local community an experienced self-government member from a neighbouring municipality was such an advisor. In yet another one, when there was a conflict with the executive body, a councillor turned to regional self-government for help: I looked for this solution on my own as a councillor, so I had to search higher than in the municipality or by the mayor. I met a representative of a regional self-government who was a member of a marshal's office. I knocked at someone's door and people were surprised, wondering what I can possibly want from them $(\mathrm{O} 2 \mathrm{w})$. It is worth mentioning that the interviewees hardly ever talked about institutions or entities from outside their local community.

In local communities there are heterogeneous groups, entities supporting the executive body. Conducted research shows which group supports the executive body in their work the most. Councilors are a visibly dominant group. The most important support group are also self-government employees including lawyers hired by the municipality.

6

\section{Conclusion}

The aim of the research was to point out entities, people and organisations which support the mayor in the decision-making process and design local development policy in municipalities with cohabitation in Poland. Research shows that this environment (support) of the mayor can be divided into two groups: internal (councilors, local government employees) and external entities (entrepreneurs, representatives of NGOs or the Catholic Church, rural leaders, voluntary fire brigades). Empirical research (questionnaires and interviews) demonstrates that there is some discrepancy as to which category most frequently backs the executive body in his/her work. As seen from the questionnaires, councilors clearly dominate in this respect, although it depends on the relationships between the authorities in the municipality. The more often the respondents evaluate this relation as very good or good, the more often they choose councilors as the main 
support group for the mayor. There are municipalities where councilors are not the dominant group of support for the executive. This is so for several reasons:

- conflict between the authorities (conflict cohabitation),

- lack of preparation and low competencies of councilors, especially in the legal and administrative field (some councilors have poor knowledge of their rights and duties),

- lack of experience of councilors, as a result of which it is the mayor who supports councilors,

- $\quad$ some councilors focus on settling matters for their constituencies, instead of acting as a collective body in the interests of the whole local community,

- $\quad$ public officials lend the mayor greater support.

On the other hand, empirical research (questionnaires) suggests that, irrespective of the type of cohabitation, local government employees, including legal advisors hired by the municipality, constitute the most important support group. In some municipalities officials try to maintain the existing status quo, and perceive a change of the mayor as unfavourable. Moreover, officials usually back the mayor, because they are his/her subordinates, while in the case of small units of local government the municipal office can be the biggest employer. In municipalities with conflict cohabitation, the opposition accuses the existing organisational and administrative structure of strengthening and preserving the mayor's position. Such a situation reveals systemic inequality between the authorities in the municipality. It seems that this disproportion was noticed by the legislator, because new legal regulations, strengthening the position of the municipal council, were introduced in 2018, so that now the head of the municipal council can issue official orders to municipal office employees, who carry out organisational, legal and other tasks connected with the functioning of the municipal council (Act on Amendment to Some Acts to Increase Citizens' Participation in the Process of Electing, Functioning and Controlling Some Public Bodies dated 11 January 2018 (Dz. U. [Journal of Laws] of 2018, item 130)).

In the group of external entities, the mayor can rely on support from nongovernmental organisations, entrepreneurs, the Catholic Church, village administrators and volunteer fire brigades. NGOs and the Catholic Church play a substantial role on the socio-political map of the municipality. Their activity and broader awareness of municipal issues can lead to these entities being willing or forced to express their support for one side in the conflict when there is conflict cohabitation. However, it entails the risk of boosting the authority of power at the expense of diminishing their own. In the event of conflict cohabitation, NGOs backing either of the sides, either the municipal council or the mayor, can lose their independence. 
Entrepreneurs get involved in the activities led by local government/office when they discern notable benefits (e.g. for their business) or when the executive body seeks their support (e.g. by asking them to finance various local initiatives).

The research question about whether groups of support vary depending on the type of municipality (rural, urban or urban-rural) should be answered affirmatively. A political party is a crucial source of support for the mayor in cities. Political parties are not deeply ingrained in Polish local government, i.e. they function, first and foremost, in big cities and small towns. At the level of rural and urban-rural municipalities, on the other hand, councilors run as candidates of a citizens' electoral committee rather than a political party. This is why auxiliary units to the municipality, that is village administrator's offices, still play a significant role. In Poland, the rural leader enjoys authority in his/her rural municipality. Besides, volunteer fire brigades, comprising residents of villages, can also have an influence on the political support for the mayor.

The executive body can count on different support groups. These are, to a large extent, entities which depend on the mayor in official, organisational or financial respects. In the case of conflict cohabitation, this institutional inequality between the mayor and the council grows even more. This is because formal or non-formal dependencies can come to the fore in the dispute. However, legal provisions are necessary to develop pluralistic and democratic order in local communities and active and conscious residents, who elect competent and community-oriented representatives of local authorities.

\section{Acknowledgment:}

The scientific paper prepared as part of NCN OPUS 6, HS5 grant entitled Koabitacja na poziomie gminnym w Polsce [Cohabitation at the municipal level in Poland], agreement no. UMO-2013/11/B/HS5/03537.

\footnotetext{
Notes:

${ }^{1}$ Municipal government in Poland was established as a result of abolishing the system of national councils. It entailed overcoming several monopolies: 1) political monopoly of the communist party, 2) monopoly of uniform state authority, 3) monopoly of state ownership, 4) financial monopoly, and 5) monopoly of state administration (Regulski 2002: 24)

${ }^{2}$ Characterising the group of the examined local government employees, the majority of them were men (66 percent), and only about a third of questionnaires were filled in by women. More than half of the respondents (57.4 percent) came from rural municipalities, a quarter from urban-rural municipalities (25.4 percent), and the smallest group was that of city inhabitants (17.2 percent). The biggest group of the respondents (49.2 percent) comprised councilors and mayors who fulfilled their function/mandate for the first time, while for the rest the 2014-2018 term of office was their second, third or fourth in the municipal council or the executive body. As far as affiliation with a club or an informal group of councilors (when the council is not divided into clubs) is concerned, 34.1 percent of the respondents were councilors of the coalition, 34.1 percent independent (not
} 
associated) councilors and 11.1 percent - councilors of the opposition. Six percent of mayors participated in the survey.

${ }^{3}$ The local community can dismiss not only the mayor, but also the municipal council by way of a referendum.

${ }^{4} 92$ percent of non-governmental organisations in Poland declare contacts with municipal self-government. See: Polskie organizacje pozarządowe 2015, Stowarzyszenie Klon/Jawor, Warszawa 2015, p. 16.

5 The referendum was invalid on account of a low voter turnout.

\section{References:}

Act on Amendment to Some Acts to Increase Citizens' Participation in the Process of Electing, Functioning and Controlling Some Public Bodies dated 11 January 2018 (Dz. U. [Journal of Laws] of 2018, item 130).

Bachrach P. \& Baratz M.S. (1962) The Two Faces of Power, American Political Science Review, 56, pp. 947-952.

Bodio, T. \& Załęski, P. (2007) Przywództwo i elity polityczne, In: Wojtaszczyk, K. A. \& Jakubowski W. (eds.) Spoleczeństwo i polityka. Podstawy nauk politycznych (Warszawa: Aspra JR F.H.U).

Chmaj, M., Sokół, W. \& Żmigrodzki, M. (1997) Teoria partii politycznych (Lublin: Maria Curie-Skłodowska University).

Cooper, C.A., Nownes A. J., \& Roberts S. (2005) Perceptions of Power: Interest Groups in Local Politics, State and Local Government Review, 37 (3) pp. 206-216.

Dahl R.A. (1961) Who Governs? Democracy and Power In an American City (New Haven: Yale University Press).

Drzonek M. (2013) Reelekcje prezydentów miast $w$ wyborach bezpośrednich $w$ Polsce (Kraków: Dante).

Hunter F. (1953) Community Power Structure: A study of Decision Makers (Chapel Hill: University of North Carolina Press).

Ihrke, D. M., Niederjohn M. S. (2005) Conflict on city councils in Wisconsin, Journal of Urban Affairs, 27(4), pp. 453-462.

Kurczewska, J. (2008) (ed.) Oblicza lokalności. Ku nowym formom życia lokalnego (Warszawa: Institute of Philosophy and Sociology Polish Academy of Sciences).

Larsen H.O. (2005) Transforming political leadership: Models, trends and reforms, In: Berg, R. \& Rao, N. (eds.) Transforming political leadership (New York: Palgrave Macmilan).

Local Government Act dated 8 March 1990 (consolidated text: Dz. U. [Journal of Laws] of 2017, items 1875,2232$)$.

Matysiak, I. (2014) Rola sołtysów we wspótczesnych społecznościach wiejskich. Płeć jako czynnik różnicujacy kapitał społeczny (Warszawa: Scholar).

Milczarek-Andrzejewska D. \& Tłaczała P. (2012) Analiza grup interesu. In: Wilkin, J. (ed.) Teoria wyboru publicznego. Glówne nurty i zastosowania (Warszawa: Scholar).

Nelson K., \& Nollenberger K. (2011) Conflict and Cooperation in Municipalities Do Variations in Form of Goverment Have an Effect?, Urban Affairs Review, 47(5), pp. 696-720.

Nocoń J. (2008) Kryteria wyłaniania lokalnych liderów politycznych, In Michałowski, S. \& Kuć-Czajkowska, K. (eds.) Przywództwo lokalne a ksztaltowanie demokracji partycypacyjnej (Lublin: Maria Curie-Skłodowska University Press). 
Olech, A. (ed.) (2013) Przepis na uczestnictwo. Diagnoza partycypacji w Polsce (Warszawa: Instytut Spraw Publicznych).

Page, E. (1991) Localism and Centralism in Europe. The Political and Legal Bases of Local Self-Government (Oxford: Oxford University Press).

Polskie organizacje pozarządowe 2015 (2015) Stowarzyszenie Klon/Jawor (Warszawa: Stowarzyszenie Klon/Jawor).

Regulski, J. (2002) Polski samorząd po dziesieciu latach. In: Michałowski S. (ed.) Samorząd terytorialny III Rzeczypospolitej. Dziesięć lat doświadczeń (Lublin: Maria Curie-Skłodowska University Press).

Regulski, J. (2005) Samorządna Polska (Warszawa: Szklane Domy).

Robbins, S. P. \& DeCenzo, D. A. (2002) Podstawy zarzadzania (Warszawa: Polskie Wydawnictwo Ekonomicze).

Sidor, M., Kuć-Czajkowska, K. \& Wasil, J. (2017) Koabitacja na poziomie gminnym w Polsce (Warszawa: Scholar).

Stokłosińska D. (2015) Pojęcie, cechy i rola lidera społeczności lokalnej, In. Staszewska, S. (ed.) Wybrane współczesne aspekty rozwoju miast i obszarów wiejskich. Prace z zakresu gospodarki przestrzennej, Series: Studia i Prace z Geografii no. 50 (Poznań: Bogucki Wydawnictwo Naukowe).

Svara J. H. (1998) The politics-administration dichotomy model as aberration, Public Administration Review, 58, pp. 51-58.

Svara J. H. (1987) Mayoral Leadership in Council - Manger Cities: Preconditions versus Preconceptions, The Journal of Politics, 49(1), pp. 207-227.

Szczepański, M. S. (2018) Ojczyzny prywatne i system światowy: społeczności lokalne $i$ regionalne a ład kontynentalny $i$ globalny, available at http://polona.pl/item/37242466 (June 12, 2020).

Sztumski, J. (2014) Elity ich miejsce i rola w spoleczeństwie (Katowice: Wydawnictwo Śląsk).

Tanguay, A. B. \& Kay, B. J. (1991) Political Activity of Local Interest Groups. In: Leslie Seidle, F. (ed.) Interest groups and Elections in Canada (Canada: Dundurn Press Toronto and Oxford).

Tuziak, B. (2014) Autorytet władz gminnych a rozwój społeczności lokalnych. Studium socjologiczne (Warszawa: Scholar).

Wiatr, J. J. (2008) Przywództwo polityczne. Studium politologiczne (Łódź: Wyższa Szkoła Humianistyczno-Ekonomiczna w Łodzi).

Wolman, H. (1996) Local Government Institutions and Democratic Governance, In: Judge, D., Stoker G., \& Wolman H., (eds.) Theories of Urban Politics (London: Sage Publications ).

Wright Mills C. (1956) The Power Elite (New York: Oxford University Press).

Żyromski M. (1984) Socjologiczna teoria elit, Ruch Prawniczy, Ekonomiczny $i$ Socjologiczny, 46(3), pp. 267-278. 
M. Sidor, K. Kuć-Czajkowska, J. Wasil: Supporting and Non-supporting Entities of the Mayor in Polish Municipalities with Cohabitation

\section{Appendix:}

Table 1: Groups of support for the mayor and evaluation of relationships between the municipal authorities by councillors and mayors

\begin{tabular}{|c|c|c|c|c|c|c|c|c|}
\hline \multirow{2}{*}{\multicolumn{2}{|c|}{$\begin{array}{l}\text { Most considerable support for } \\
\text { mayor's work: according to the } \\
\text { respondents (councillors, mayors) }\end{array}$}} & \multicolumn{6}{|c|}{$\begin{array}{l}\text { Relationships between the authorities in municipalities as } \\
\text { seen by councillors and mayors }\end{array}$} & \multirow[t]{2}{*}{ Total } \\
\hline & & $\begin{array}{l}\text { Very } \\
\text { good }\end{array}$ & Good & Average & $\mathrm{Bad}$ & $\begin{array}{l}\text { Very } \\
\text { bad }\end{array}$ & $\begin{array}{c}\text { No } \\
\text { answer }\end{array}$ & \\
\hline \multirow[t]{2}{*}{ Councillors } & $\mathrm{N}$ & 296 & 398 & 126 & 20 & 4 & 6 & 850 \\
\hline & $\%$ & 34.8 & 46.8 & 14.8 & 2.4 & 0.5 & 0.7 & 100 \\
\hline \multirow{2}{*}{ Local entrepreneurs } & $\mathrm{N}$ & 7 & 24 & 14 & 7 & 2 & 1 & 55 \\
\hline & $\%$ & 12.7 & 43.6 & 25.5 & 12.7 & 3.6 & 1.8 & 10 \\
\hline \multirow[t]{2}{*}{ Local community } & $\mathrm{N}$ & 46 & 59 & 46 & 15 & 2 & 2 & 170 \\
\hline & $\%$ & 27.1 & 34.7 & 27.1 & 8.8 & 1.2 & 1.2 & 10 \\
\hline \multirow[t]{2}{*}{ NGOs representatives } & $\mathrm{N}$ & 4 & 11 & 17 & 2 & 2 & 0 & 36 \\
\hline & $\%$ & 11.1 & 30.6 & 47.2 & 5.6 & 5.6 & 0 & 100 \\
\hline \multirow{2}{*}{$\begin{array}{ll}\text { Municipal government } \\
\text { employees }\end{array}$} & $\mathrm{N}$ & 10 & 19 & 16 & 7 & 4 & 0 & 56 \\
\hline & $\%$ & 17.9 & 33.9 & 28.6 & 12.5 & 7.1 & 0 & 10 \\
\hline \multirow{2}{*}{$\begin{array}{ll}\begin{array}{l}\text { Councillors, } \\
\text { community }\end{array} & \text { local } \\
\end{array}$} & $\mathrm{N}$ & 61 & 61 & 10 & 0 & 0 & 1 & 133 \\
\hline & $\%$ & 45.9 & 45.9 & 7.5 & 0 & 0 & 0.8 & 100 \\
\hline \multirow{2}{*}{$\begin{array}{l}\text { Councillors, } \\
\text { entrepreneurs }\end{array}$} & $\mathrm{N}$ & 11 & 18 & 9 & 1 & 1 & 0 & 40 \\
\hline & $\%$ & 27.5 & 45 & 22.5 & 2.5 & 2.5 & 0 & 100 \\
\hline \multirow{2}{*}{$\begin{array}{ll}\text { Councillors, } & \text { NGOs } \\
\text { representatives } & \\
\end{array}$} & $\mathrm{N}$ & 24 & 30 & 10 & 1 & 0 & 1 & 66 \\
\hline & $\%$ & 36.4 & 45.5 & 15.2 & 1.5 & 0 & 1.5 & 100 \\
\hline \multirow[t]{2}{*}{ Most of these groups } & $\mathrm{N}$ & 79 & 59 & 10 & 4 & 0 & 0 & 152 \\
\hline & $\%$ & 52 & 38.8 & 6.6 & 2.6 & 0 & 0 & 100 \\
\hline \multirow[t]{2}{*}{ Other } & $\mathrm{N}$ & 3 & 15 & 21 & 14 & 6 & 1 & 60 \\
\hline & $\%$ & 5.0 & 25.0 & 35.0 & 23.3 & 10 & 1.7 & 100 \\
\hline \multirow[t]{2}{*}{ Don’t know } & $\mathrm{N}$ & 5 & 7 & 9 & 1 & 0 & 0 & 22 \\
\hline & $\%$ & 22.7 & 31.8 & 40.9 & 4.5 & 0 & 0 & 100 \\
\hline \multirow[t]{2}{*}{ No answer } & $\mathrm{N}$ & 28 & 41 & 17 & 5 & 2 & 4 & 97 \\
\hline & $\%$ & 28.9 & 42.3 & 17.5 & 5.2 & 2.1 & 4.1 & 100 \\
\hline \multirow[t]{2}{*}{ Total } & $\mathrm{N}$ & 574 & 742 & 305 & 77 & 23 & 16 & 1737 \\
\hline & $\%$ & 33 & 42.7 & 17.6 & 4.4 & 1.3 & 0.9 & 100 \\
\hline
\end{tabular}

Source: own research.

Note. V Cramer is 0.2 [V Cramer means that the closer a variable to 1.0 , the stronger the examined association]. 